\title{
Bilateral Hepatic Subcapsular Biloma: A Rare Case Report
}

\author{
Triyanta Yuli Pramana' ${ }^{1}$, Widiastuti²) \\ ${ }^{1)}$ Gastroenterology and Hepatology Division, Internal Medicine Department, \\ Faculty of Medicine Universitas Sebelas Maret / Dr. Moewardi hospital Surakarta. \\ 2)Radiology Department, Faculty of Medicine, Universitas Sebelas Maret/ \\ Dr. Moewardi Hospital, Surakarta
}

\section{ABSTRACT}

Background: Biloma is loculated collection of bile that may develop due to iatrogenic causes, traumatically or spontaneously with biliary tree disruption. Hepatic bilateral subcapsular biloma is a rare complication of laparoscopic cholecystectomy and an even more scarce when it occurs spontaneously.

Case Presentation: A 65 years old man came to our hospital with abdominal pain and enlarged abdomen. Six weeks earlier he underwent laparoscopic cholecystectomy in a private hospital, because of stone in the gall bladder and cholecystitis. The physical examination obtained no icteric and distended abdomen with pain on palpation. Laboratory findings were within normal limit with negative viral infection markers. Abdominal ultrasonography revealed chronic liver disease with giant liver cyst and ascites. Contrast abdominal multi-slice computed monography (MSCT) demonstrated bilateral hepatic subcapsular biloma. Laparatomy and drainage were then performed and he was discharged from the hospital several days later in good condition. Discussion: Biloma was first introduced by Gould and Patel in 1979. The incidence of past laparoscopic cholecystectomy biloma is very low, between $0.6 \%$ and 1.5\%. Early accurate diagnosis is very important to determine the proper management. In our case, the biloma was found by using USG and MSCT. Usually it presents with right upper quadrant or epigastric pain, abdominal distention, fever and leukocytosis, but our patient did not have either fever or leukocytosis. Actually the first treatment choice is percutaneous catheter drainage but in our case laparotomy drainage was performed because of subcapsular, biloma in both right and left hepatic lobes.

Conclusion: Bilateral hepatic subcapsular bilo$\mathrm{ma}$ is a rare case. One of its diagnostic tools is MSCT. Biloma drainage is the first choice of treatment.

Keywords:Biloma, post laparoscopic cholecystectomy, drainage

\section{Correspondence:}

Triyanta Yuli Pramana. Department of Gastroenterology and Hepatology Division, Dr. Moewardi Hospital/ Faculty of Medicine, Universitas Sebelas Maret. Email: typramana@gmail.com

\section{Cite this as:}

Pramana TY, Widiastuti (2020). Bilateral Hepatic Subcapsular Biloma: A Rare Case Report. Indones J Med. 05(01): 52-56. https://doi.org/10.26911/theijmed.2020.05.01.08

cc (7) (-) Indonesian Journal of Medicine is licensed under a Creative Commons Attribution-NonCommercial-ShareAlike 4.o International License.

\section{BACKGROUND}

Biloma is defined as an encapsulated collection of bile in extra-biliary tract, it is due to the complications of biliary tract surgery, ERCP procedure, laparoscopic cholecystectomy, trauma and some occur spontaneously (Dupas et al., 2016; Peng and Wang, 2017; Shankar et al., 2003). Biloma also can develop in Sickle Cell disease(Lebensburger et al., 2008), and a complication of radiofreqency ablation (Report, 2003). Intrahepatic Biloma Formation (Bile Duct Necrosis) After Transcatheter Arterial Chemoembolization (Sakamoto et al., 2003).

Hepatic subcapsular biloma resulting from laparoscopic cholecystectomy is rare (Brown et al., 2017). Mostly bile leaks to 
peritoneal cavity. If there is subcapsular biloma usually it is only one side, either right or left lobe. Here we report a case of bilateral hepatic subcapsular biloma.

\section{CASE PRESENTATION}

A 65 years old man admitted to Dr Moewardi hospital due to enlarged painful abdomen for two days. Before admission, the pain persisted, did not improve with rest, consuming food or pain killer. He did not vomit just felt full stomach. His appetite decreased. He had no fever. One and a half months before admission, this patient complained for pain in the right upper abdomen and he was diagnosed with gallstone and gallbladder inflamemation. He then underwent laparoscopic cholecystectomy. The operation went well,

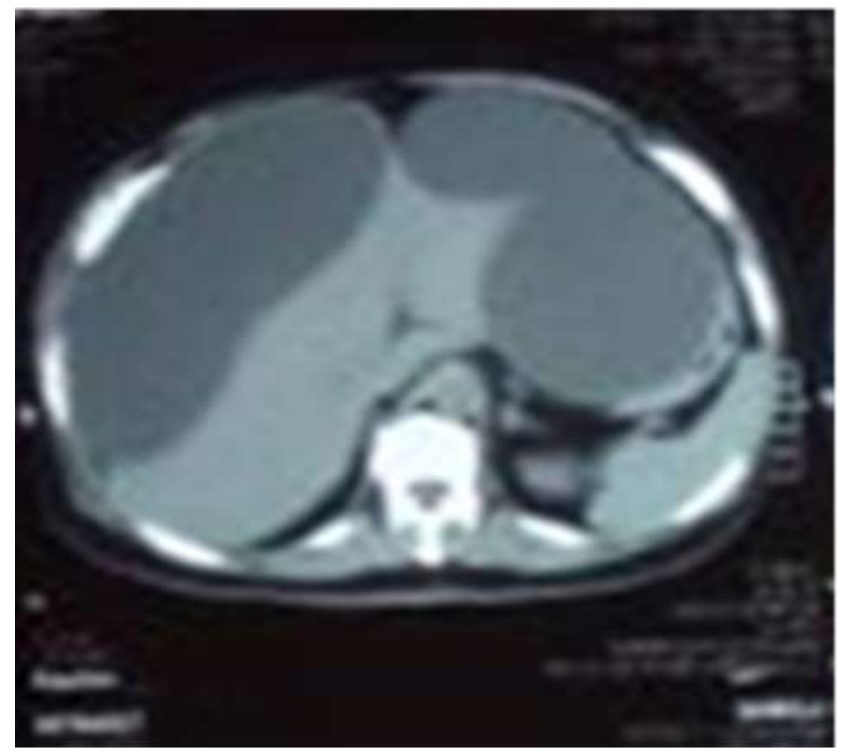

Figure 1. Hepatic subcapsularbiloma appearance in bilateral lobes

Contrasted abdominal MSCT demonstrated fluid collection in subcapsular perihepatic comprising right and left lobes with the sizes of $17.9 \times 12 \times 18.4 \mathrm{~cm}$ and $20.7 \times 11 \times 15.7 \mathrm{~cm}$, respectively, supporting the diagnosis of bilateral subcapsular biloma. Figure 1.

Laparotomy and biloma drainage were performed. Biloma drainage analysisobtained there was no complained after wards and his condition improved thus he was discharged. In the next visit after discharge, his condition was declared good.

In the course of time, his abdomen enlarged with discomfort sensation and even more painful. He went back to the hospital and was referred to Dr. Moewardi hospital.

In Dr .Moewardi hospital, he was fully alert with unremarkable vital signs. The laboratory findings were $\mathrm{Hb}$ of $12.5 \mathrm{~g} / \mathrm{dl}$, leukocyte of 7.7 thousand/Ul, thrombocyte of 513,000 / Ul, SGPT of 28, albumin of 2.6, total bilirubin of $0.43 \mathrm{mg} / \mathrm{dl}$ and creatinine of $1.2 \mathrm{mg} / \mathrm{dl}$. The abdominal ultrasonography revealed large cyst with septa and internal echo.

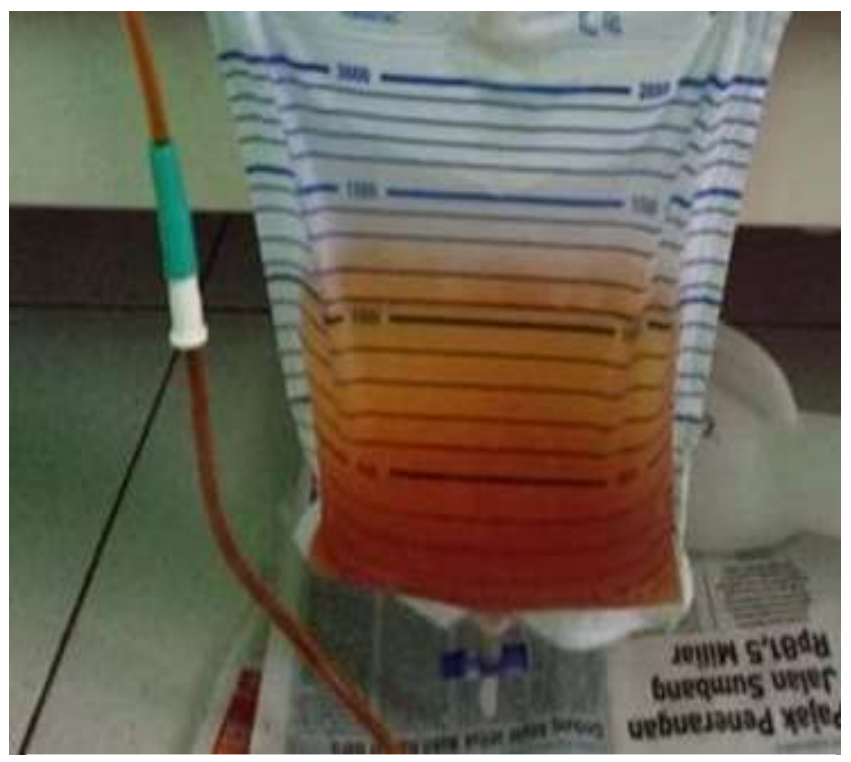

Figure 2. Drained fluid of biloma

total bilirubin of $33.47 \mathrm{mg} / \mathrm{dl}$, direct bilirubin of $23.34 \mathrm{mg} / \mathrm{dl}$ and indirect bilirubin of 10.13 $\mathrm{mg} / \mathrm{dl}$.

\section{DISCUSSION}

This term of biloma was first introduced by Gould 2nd Patel in 1979 to describe an encapsulated collection of bile in the outside 
biliary duct (Shankar et al., 2003). Kuligowska et al. (1983) broadened the definition by involving intrahepatic bile collection. Hepatic subcapsular biloma rarely occurs due to laparoscopic cholecystectomy. Generally it is located in Morrison cavum or subhepatic ventral space (Dupas et al., 2016). The incidence rate of biliary duct injury due to open cholecystectomy is estimated $0.1 \%$ while in laparoscospic cholecystectomy is about $0.6 \%$ - 1.5\% (Braithwaite et al., 2003).

Some studies suggest that biloma occurs because of backpressure associated with high-pressure irrigation during surgery. We did not perform cholangiography in our patient. Thus we suspected that hepatic subcapsular biloma occurred in our patient was due to biliary duct disturbance near gallbladder during dissection as this process is extremely difficult.

There is possibility that the introgenic injury resulted from the electric chauterization during the procedure causing bile leakage from biliary duct to hepatic subcapsular. The stretch of glisson capsule can lead to pain in the right hypochondriac region (Stathopoulos et al., 2014).

Biloma syndrome can be obtained from history taking and physical examination. Usually patients complain for pain in the right upper abdomen, the abdomen enlarges and sometimes icteric body as well as teacoloured urine. In our case, the patient also complained pain the right upper abdomen and enlarged abdomen. He also had undergone laparoscopic cholecystectomy which is a risk factor of biloma(Brown et al., 2017).

The diagnosis of biloma can be established with imaging. Liver function and bile duct are not affected and blood laboratory examination findings are within normal limit. Imaging modalities used are abdominal USG, CT-scan, and hepatobilliary scintigraphy. In USG and CT-scan findings confirmed the diagnosis of hepatocyst (Tana,
2013). In our case, USG and CT-scan findings confirmed the diagnosis of hepatic subcapsular biloma. If it is necessary MRCP, an obtimalized MRI procedure is used to evaluate the condition of biliary duct. It can show the anatomy of biliary duct and evaluate the biloma (Solomon et al., 2016).

Biloma management may vary. If biloma issmall, no treatment is required and only observation is enough. Some studies report that there is no neded for surgical exploration, since biloma is self limiting (Tamura et al., 2015) .

The other situations can be performed percutaneous aspiration, percutaneous catheter drainage, surgical drainage to overt surgical treatment(Okello et al., 2018) . Piraka (2009) gived a report EUS-guided transgastric drainage of biloma successfully (Piraka et al., 2009).

We conducted laparotomy and drainage instead of percutaneous drainage because our patient had bilateral hepatic subcapsular biloma and six days after biloma drainage, the patient condition improved and discharge from the hospital, was evaluated in outpatient clinic.

This case study concludes that bilateral hepatic subcapsular biloma is rare. MSCT is one of modalities to diagnose this type of biloma. The first choice of treatment is drainage.

\section{AUTHOR CONTRIBUTION}

Triyanta Yuli Pramana did USG and MSCT. Widiastuti did laboratory test.

\section{CONFLICT OF INTEREST}

None

\section{FUNDING AND SPONSORSHIP}

None

ACKNOWLEDGEMENT

We would like to thank to Dr Moewardi Hospital's and Medical Faculty Universitas 
Sebelas Maret Surakarta for giving permission to collect the data.

REFERENCE
Braithwaite BM, Cabanilla LT, Lilly M
(2003). Hepatic subcapsular biloma:A
rare complication of laparoscopic cho-
lecystectomy and common bile duct
exploration. Curr Probl Surg, 6o(2):
196-198. https://doi.org/10.1016/So1-
49-7944(02)o0738-9

Brown S, Giuseppucci P, Esper C (2017). Rare reported left hepatic subcapsular biloma and management. Case Rep Surg, 1-3. https://doi.org/10.1155/2017/8609185.

Dupas JL, Mancheron H, Sevenet F, Delamarre J, Delcenserie R, Capron JP (2016). Hepatic subcapsular biloma. Gastroenterology, 94(5): 1225-1227. https://doi.org/10.1016/o016-5085(88)90017-0

Sakamoto I, Iwanaga S, Nagaoki K, Matsuoka Y, Ashizawa K, Uetani M, Fukuda T, Okimoto T, Okudaira S, Omagari K, Hayashi K, Matsunaga N (2003). Intrahepatic biloma formation (bile duct necrosis) after transcatheter arterial chemoembolization. AJR Am J Roentgenol. 181(1): 79-87. https://doi.org/10.2214/ajr.181.1.1810079

Kuligowska E, Schlesinger A, Miller KB, Lee VW, Grosso D (1983). Bilomas: A new approach to the diagnosis and treatment. Gastrointest Radiol,8(1): 237243. https://doi.org/10.1007/BFo1948126

Lebensburger J, Esbenshade A, Blakely M, Wang W, Hankins J (2008). Biloma and pneumobilia in sickle cell disease. Pediatr Blood Cancer, 51: 288-290. https://doi.org/10.1002/pbc.

Okello TR, Ocen D, Okello J, Pecorella I, Amone D (2018). Case report: Biloma gastrostomy after failed sonogram- guided percutaneous aspiration, pigtail catheter insertion and surgical drainage. AAS Open Research, 1: 19. https://doi.org/10.12688/aasopenres.12876. 1

Peng CZ, Wang CY (2017). Giant intrahepatic biloma following blunt hepatic injury. Can J Emerg Med Care, 19(1): 61-62. https://doi.org/10.1017/cem.2015.106 Piraka C, Shah RJ, Fukami N, Chathadi KV, Chen YK (2009). EUS-guided transesophageal, transgastric, and transcolonic drainage of intra-abdominal fluid collections and abscesses. Gastrointest Endosc, 70(4): 786-792. https://doi.org/10.1016/j.gie.2009.04.049.

Shankar S, VanSonnenberg E, Silverman SG, Tuncali K, Morrison PR (2003). Diagnosis and treatment of intrahepatic biloma complicating radiofrequency ablation of hepatic metastases. AJR Am J Roentgenol, 181(2): 475-477. https://doi.org/10.2214/ajr.181.2.1810475

Solomon SB, Griffin JF, Weiss MJ, Boas FE (2016). Postoperative complications requiring intervention: Diagnosis and management. In Blumgart's Surgery of the Liver, Biliary Tract and Pancreas: Sixth Edition, 1(2) : 27. https://doi.org10.1016/B978-0-323-34062-5.00027-3 Stathopoulos V, Georganas M, Stratakis K, Delaporta E, Karallas E, Koutsopoulos K (2014). Case report hepatic subcapsular biloma: A Rare Complication of Laparoscopic Cholecystectomy. Case Rep Surg. 3-6. https://doi.org/10.1155/2014/186819

Tamura N, Ishihara S, Kuriyama A, Watanabe S, Suzuki K (2015). Long-term follow-up after non-operative management of biloma due to blunt liver injury. World J Surg Oncol, 39(1): 179183. https://doi.org/10.1007/s00268o14-2780-z 
Pramana et al./ Bilateral Hepatic Subcapsular Biloma

Tana C (2013). Sonographic assessment of a 5(5): 220. https://doi.org/10.4329/wjrsuspected biloma: A case report and .v5.i5.220.

review of the literature. World J Radiol, 